Pacific Journal of Mathematics

CERTAIN ALGEBRAS OF DEGREE ONE 


\title{
CERTAIN ALGEBRAS OF DEGREE ONE
}

\author{
Frank Kosier
}

In this note the following is proved: Suppose $R$ is a finitedimensional algebra over an algebraically closed field $F$ of characteristic 0 whose associator satisfies $4(y, x, x)=4(x, y, x)$ $+[[y, x], x]$ and $(x, x, x)=0$. If $R$ is simple and non-nil then $R$ is iso-morphic to $F$.

We call it Theorem $\mathrm{B}$, and prove it below.

In [3] nonassociative algebras satisfying identities of degree three were studied and it was shown that relative to quasi-equivalence any algebra satisfying such an identity (subject to some rather weak additional hypotheses) must in fact satisfy at least some one of seven particular identities; each of degree three. In this note we concern ourselves with one of these seven residual cases; namely the identity

$$
4(y, x, x)=4(x, y, x)+[[y, x], x]
$$

where the associator $(x, y, z)$ is defined by $(x, y, z)=(x y) z-x(y z)$ and the commutator $[x, y]$ by $[x, y]=x y-y x$ for elements $x, y, z$ of the algebra.

Throughout the remainder of this note $R$ will be a ring of characteristic not two or three which satisfies (1) in addition to the following identity:

$$
(x, x, x)=0 .
$$

The following result was established in [3]:

Theorem A. Suppose $R$ has an idempotent $e \neq 0,1$. Then $R$ is not simple.

This reduces the study of simple rings to the consideration of rings whose only nonzero idempotent is the identity element.

Ideals and Simple rings. A well-known consequence of (2) is

$$
(x, x, y)+(x, y, x)+(y, x, x)=0 .
$$

We define $x \circ y=x y+y x$ and proceed to simplify (1). We rewrite (1) as

$$
4 y x^{2}=4 x \circ y x-3(x y) x-x(x y)-(y x) x+x(y x)
$$

and (3) as

Received April 6, 1964. 


$$
2 y x^{2}=x^{2} \circ y+(x y) x+(y x) x-x(y x)-x(x y) .
$$

Adding (4) and (5) we obtain

$$
6 y x^{2}=x^{2} \circ y+4 x \circ y x-2 x \circ x y .
$$

Finally we add and subtract $2 x \circ y x$ to the right-hand member of (6) giving us

$$
6 y x^{2}=6 x \circ y x-2 x \circ(x \circ y)+x^{2} \circ y .
$$

Replacing $x$ by $x_{1}+x_{2}$ in (7) and then using (7) to simplify the result we find

$$
\begin{aligned}
6 y\left(x_{1} \circ x_{2}\right)= & 6 x_{1} \circ y x_{2}+6 x_{2} \circ y x_{1}-2 x_{1} \circ\left(x_{2} \circ y\right) \\
& -2 x_{2} \circ\left(x_{1} \circ y\right)+\left(x_{1} \circ x_{2}\right) \circ y .
\end{aligned}
$$

We define the ring $R^{+}$to be the same additive group as $R$ but the multiplication in $R^{+}$is given by $(x, y)=1 / 2 x \circ y$. We set $(x, y, z)^{+}=$ $(x \circ y) \circ z-x \circ(y \circ z)$ and note that $R^{+}$is associative if and only if $(x, y, z)^{+}=0$ for all $x, y, z \in R$.

LEMMA 1 . Let $L$ be the additive group generated by all $(x, y, z)^{+}$ where $x, y, z \in R$. Then $L$ is a left ideal of $R$.

Proof. First of all we consider $y\left[\left(x_{1} \circ x_{2}\right) \circ x_{3}\right]$. Then (8) (with $x_{1}$ replaced by $x_{1} \circ x_{2}$ and $x_{2}$ by $x_{3}$ ) becomes

$$
\begin{aligned}
6 y\left[\left(x_{1} \circ x_{2}\right) \circ x_{3}\right]= & 6\left(x_{1} \circ x_{2}\right) \circ y x_{3}+6 x_{3} \circ y\left(x_{1} \circ x_{2}\right)-2\left(x_{1} \circ x_{2}\right) \circ\left(x_{3} \circ y\right) \\
& -2 x_{3} \circ\left[\left(x_{1} \circ x_{2}\right) \circ y\right]+\left[\left(x_{1} \circ x_{2}\right) \circ x_{3}\right] \circ y .
\end{aligned}
$$

We use (8) to rewrite the second term of the right-hand member of (9) as:

$$
\begin{aligned}
6 x_{3} \circ y\left(x_{1} \circ x_{2}\right)= & 6 x_{3} \circ\left(x_{1} \circ y x_{2}\right)+6 x_{3} \circ\left(x_{2} \circ y x_{1}\right)-2 x_{3} \circ\left[x_{1} \circ\left(x_{2} \circ y\right)\right] \\
& -2 x_{3} \circ\left[x_{2} \circ\left(x_{1} \circ y\right)\right]+x_{3} \circ\left[\left(x_{1} \circ x_{2}\right) \circ y\right] .
\end{aligned}
$$

A substitution of this into (9) results in

$$
\begin{aligned}
6 y\left[\left(x_{1} \circ x_{2}\right) \circ x_{3}\right]= & 6\left(x_{2} \circ x_{2}\right) \circ y x_{3}+6 x_{3} \circ\left(x_{1} \circ y x_{2}\right)+6 x_{3} \circ\left(x_{2} \circ y x_{1}\right) \\
& -2 x_{3} \circ\left[x_{1} \circ\left(x_{2} y\right)\right]-2 x_{3} \circ\left[x_{2} \circ\left(x_{1} \circ y\right)\right] \\
& -2\left(x_{1} \circ x_{2}\right) \circ\left(x_{3} \circ y\right)+\left(x_{3}, x_{1} \circ x_{2}, y\right)^{+} .
\end{aligned}
$$

If we interchange $x_{1}$ and $x_{2}$ in (10) we obtain

$$
\begin{aligned}
6 y\left[\left(x_{3} \circ x_{2}\right) \circ x_{1}\right]= & 6\left(x_{3} \circ x_{2}\right) \circ y x_{1}+6 x_{1} \circ\left(x_{3} \circ y x_{2}\right)+6 x_{1} \circ\left(x_{2} \circ y x_{3}\right) \\
& -2 x_{1} \circ\left[x_{3} \circ\left(x_{2} \circ y\right)\right]-2 x_{1} \circ\left[x_{2} \circ\left(x_{3} \circ y\right)\right] \\
& -2\left(x_{3} \circ x_{2}\right) \circ\left(x_{1} \circ y\right)+\left(x_{1}, x_{3} \circ x_{2}, y\right)^{+} .
\end{aligned}
$$


Then subtracting (11) from (10) yields

$$
\begin{aligned}
6 y\left(x_{1}, x_{2}, x_{3}\right)^{+}= & 6\left(x_{1}, x_{2}, y x_{3}\right)^{+}+6\left(x_{1}, y x_{2}, x_{3}\right)^{+}+6\left(y x_{1}, x_{2}, x_{3}\right)^{+} \\
& -2\left(x_{1}, x_{2} \circ y, x_{3}\right)^{+}+2\left(x_{3}, x_{2}, x_{1} \circ y\right)^{+} \\
& -2\left(x_{1}, x_{2} \circ x_{3}, y\right)^{+}+\left(x_{3}, x_{1} \circ x_{2}, y\right)+\left(x_{1}, x_{3} \circ x_{2}, y\right)^{+} .
\end{aligned}
$$

Thus $y L \subseteq L$ and $L$ is a left ideal of $R$.

THEOREM 1. $L+L R$ is an ideal (two-sided) of $R$.

Proof. As is immediate from Lemma 1 it suffices to show that $R(L R)+(L R) R \subseteq L+L R$. Suppose $x_{1}, x_{2} \in R, y \in L$. Then $\left(x_{1}, x_{2}, y\right)^{+} \in L$ so that $\left(x_{1} \circ x_{2}\right) \circ y-x_{1} \circ\left(x_{2} \circ y\right) \in L$. But $\left(x_{1} \circ x_{2}\right) \circ y$ and $x_{1} \circ x_{2} y$ belong to $L+L R$. Hence, $x_{1} \circ y x_{2} \in L+L R$. Next we interchange $x_{2}$ and $y$ in (8), obtaining

$$
\begin{aligned}
6 x_{2}\left(x_{1} \circ y\right)= & 6 x_{1} \circ x_{2} y+6 y \circ x_{2} x_{1}-2 x_{1} \circ\left(x_{2} \circ y\right) \\
& -2 y \circ\left(x_{1} \circ x_{2}\right)+\left(x_{1} \circ y\right) \circ x_{2} .
\end{aligned}
$$

But Lemma 1 along with the preceding remarks implies that each term of the right-hand member belongs to $L+L R$. Hence, $x_{2}\left(x_{1} \circ y\right) \in L+L R$ but $x_{2}\left(x_{1} y\right) \in R(R L) \subseteq L$ so that $x_{2}\left(y x_{1}\right) \in L+L R$. Thus, we must also have $\left(y x_{1}\right) x_{2} \in L+L R$, since $x_{2} \circ y x_{1} \in L+L R$. Therefore $R(L R)+$ $(L R) R \subseteq L+L R$ and $L+L R$ is an ideal of $R$.

Theorem 2. $L$ is an ideal of $L+L R$.

Proof. Since $L$ is a left ideal of $R$ we need only show that $L(L R) \subseteq L . \quad$ Suppose $x_{1}, x_{2} \in L, y \in R$. Then (8) implies

$$
2 x_{1}\left(x_{2} y\right)+2 x_{2}\left(x_{1} y\right)-\left(x_{1} \circ x_{2}\right) y \in L .
$$

Considering that $\left(x_{1}, x_{2}, y\right)^{+}$and $\left(x_{1}, y, x_{2}\right)^{+}$belong to $L$ we find

$$
\left(x_{1} \circ x_{2}\right) y-x_{1}\left(x_{2} y\right) \in L \text {. }
$$

and

$$
x_{2}\left(x_{1} y\right)-x_{1}\left(x_{2} y\right) \in L .
$$

Adding (13) and (14) we obtain $x_{1}\left(x_{2} y\right)+2 x_{2}\left(x_{1} y\right) \in L$. This along with (15) implies that $x_{2}\left(x_{1} y\right) \in L$ or $L(L R) \subseteq L$, as was to be shown.

COROLlary. If $R$ is simple then either $R^{+}$is associative or $L=R$.

Proof. If $R$ is simple then either $L+L R=0$ or $L+L R=R$. In the first instance $L=0$ so that $R$ is associative while in the second 
$L$ is an ideal of $R$. Hence, either $L=0$ or $L=R$.

Now suppose $R$ is a simple finite-dimensional algebra over an angebraically closed field $F$ of characteristic 0 . Then $R$ is powerassociative [3, Lemma 2] so that if $R$ is nonnil, $R$ must possess a nonzero idempotent $e$. By Theorem $\mathrm{A}$ of the Introduction we must, in fact, have $e=1$, the identity of $R$. A result of Albert's [1] states that $R=F 1+N$ where all the elements of $N$ are nilpotent and $N$ is an ideal of $R^{+}$. From this it is immediate that $(x, y, z)^{+} \in N$ for all $x, y, z \in R$ so that $L \subseteq N \neq R$. Hence, $L=0$ and $R^{+}$is associative. But then $R$ satisfies

$$
2(y, x, x)=2(x, x, y)+[[y, x], x]
$$

Subtracting this relation from (1) we have

$$
2(y, x, x)=4(x, y, x)-2(x, x, y)
$$

which along with (3) implies that $(x, y, x)=0$. Hence, $R$ is flexible and the results of Theorem $\mathrm{B}$ follow from [2].

\section{BIBLIOGRAPHY}

1. A. A. Albert, A theory of power-associative, commutative algebras, Trans. Amer. Math Soc. 69 (1950), 503-527.

2. E. Kleinfeld and L. Kokoris, Flexible algebras of degree one, Proc. Amer. Math Soc. 13 (1962), 891-893.

3. F. Kosier and J.M. Osborn, Non-associative algebras satisfying identities of degree three. Trans. Amer. Math Soc. 110 (1964), 484-492.

UNIVERSITY OF WISCONSIN AND

SYRACUSE UNIVERSITY 


\title{
PACIFIC JOURNAL OF MATHEMATICS
}

\author{
EDITORS
}

\author{
H. Samelson \\ Stanford University \\ Stanford, California \\ R. M. Blumenthal \\ University of Washington \\ Seattle, Washington 98105
}

\author{
J. DugundjI \\ University of Southern California \\ Los Angeles, California 90007 \\ Richard Arens \\ University of California \\ Los Angeles, California 90024
}

\section{ASSOCIATE EDITORS}
E. F. BECKENBACH
B. H. NEUMaNN
F. WOLF
K. YosIDA

\section{SUPPORTING INSTITUTIONS}

\author{
UNIVERSITY OF BRITISH COLUMBIA \\ CALIFORNIA INSTITUTE OF TECHNOLOGY \\ UNIVERSITY OF CALIFORNIA \\ MONTANA STATE UNIVERSITY \\ UNIVERSITY OF NEVADA \\ NEW MEXICO STATE UNIVERSITY \\ OREGON STATE UNIVERSITY \\ UNIVERSITY OF OREGON \\ OSAKA UNIVERSITY \\ UNIVERSITY OF SOUTHERN CALIFORNIA
}

\author{
STANFORD UNIVERSITY \\ UNIVERSITY OF TOKYO \\ UNIVERSITY OF UTAH \\ WASHINGTON STATE UNIVERSITY \\ UNIVERSITY OF WASHINGTON \\ AMERICAN MATHEMATICAL SOCIETY \\ CALIFORNIA RESEARCH CORPORATION \\ SPACE TECHNOLOGY LABORATORIES \\ NAVAL ORDNANCE TEST STATION
}

Mathematical papers intended for publication in the Pacific Journal of Mathematics should by typewritten (double spaced). The first paragraph or two must be capable of being used separately as a synopsis of the entire paper. It should not contain references to the bibliography. Manuscripts may be sent to any one of the four editors. All other communications to the editors should be addressed to the managing editor, Richard Arens, at the University of California, Los Angeles, California 90024.

50 reprints per author of each article are furnished free of charge; additional copies may be obtained at cost in multiples of 50 .

The Pacific Journal of Mathematics is published quarterly, in March, June, September, and December. Effective with Volume 13 the price per volume (4 numbers) is $\$ 18.00$; single issues, $\$ 5.00$. Special price for current issues to individual faculty members of supporting institutions and to individual members of the American Mathematical Society: $\$ 8.00$ per volume; single issues $\$ 2.50$. Back numbers are available.

Subscriptions, orders for back numbers, and changes of address should be sent to Pacific Journal of Mathematics, 103 Highland Boulevard, Berkeley 8, California.

Printed at Kokusai Bunken Insatsusha (International Academic Printing Co., Ltd.), No. 6, 2-chome, Fujimi-cho, Chiyoda-ku, Tokyo, Japan.

PUBLISHED BY PACIFIC JOURNAL OF MATHEMATICS, A NON-PROFIT CORPORATION

The Supporting Institutions listed above contribute to the cost of publication of this Journal, but they are not owners or publishers and have no responsibility for its content or policies. 


\section{Pacific Journal of Mathematics}

\section{Vol. 15, No. $2 \quad$ October, 1965}

Patrick Robert Ahern, On the generalized F. and M. Riesz theorem......... 373

A. A. Albert, On exceptional Jordan division algebras ................ 377

J. A. Anderson and G. H. Fullerton, On a class of Cauchy exponential

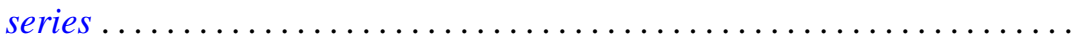

Allan Clark, Hopf algebras over Dedekind domains and torsion in

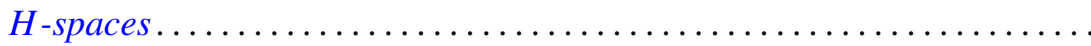

John Dauns and D. V. Widder, Convolution transforms whose inversion functions have complex roots .............................

Ronald George Douglas, Contractive projections on an $\mathrm{L}_{1}$ space ..........

Robert E. Edwards, Changing signs of Fourier coefficients ...............

Ramesh Anand Gangolli, Sample functions of certain differential processes on symmetric spaces .....................................

Robert William Gilmer, Jr., Some containment relations between classes of

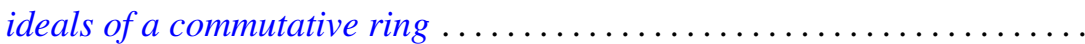

Basil Gordon, A generalization of the coset decomposition of a finite

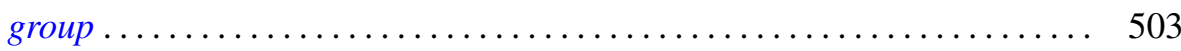

Teruo Ikebe, On the phase-shift formula for the scattering operator....... 511

Makoto Ishida, On algebraic homogeneous spaces ................ 525

Donald William Kahn, Maps which induce the zero map on homotopy ........ 537

Frank James Kosier, Certain algebras of degree one ................. 541

Betty Kvarda, An inequality for the number of elements in a sum of two sets of lattice points.................................

Jonah Mann and Donald J. Newman, The generalized Gibbs phenomenon for regular Hausdorff means. .

Charles Alan McCarthy, The nilpotent part of a spectral operator. II . ...

Donald Steven Passman, Isomorphic groups and group rings ...

R. N. Pederson, Laplace's method for two parameters .....

Tom Stephen Pitcher, A more general property than domination for sets of probability measures .............................

Arthur Argyle Sagle, Remarks on simple extended Lie algebras. .

Arthur Argyle Sagle, On simple extended Lie algebras over fields of

characteristic zero.

Tôru Saitô, Proper ordered inverse semigroups ...........

Oved Shisha, Monotone approximation

Indranand Sinha, Reduction of sets of matrices to a triangular form

Raymond Earl Smithson, Some general properties of multi-valued

functions .................................

John Stuelpnagel, Euclidean fiberings of solvmanifolds .... 